\title{
COMPARISON BETWEEN OBSER VED AND CALCULATED DISTRIBUTIONS OF TRACE SPECIES IN THE MIDDLE ATMOSPHERE
}

\section{G. Brasseur* and A. DeRudder**}

*National Center for Atmospheric Research, Boulder, CO 80307

**Belgian Institute for Space Aeronomy, 1180 Brussels, Belgium

\section{NTRODUCTION}

The number density of atmospheric minor constituents is characterized by large temporal and opatial variability. In the case of long-tived species auch as the "wurce gases" $\left(\mathrm{N}_{2} \mathrm{O}, \mathrm{CH}\right.$, the chlorofluorocarbons, ek.). transport processes may account for much of this variability. In the case of fast-reacting pecies such a chemical radicals $\left(\mathrm{OH}, \mathrm{HO}_{2}, \mathrm{O}, \mathrm{NO}, \mathrm{Cl}\right.$, etc.), a large fraction of the variability is produced by the diurna and aceonal variation of the wolar insolation. However, a these radicals are usually produced by eneraical or photochemical decomposition of long-lived apecies, their distribution is aso ind irectly controlied by irarspon proceases. Finally, in the case of species whose chemical lifetime is approximately equal to the transport cheracteristic time of the atmosphere (ozone and nitric acid in tibe middle stratoaphere, texporary reservoirs such a $\mathrm{HO}_{2} \mathrm{NO}_{3}, \mathrm{ClONO}, \mathrm{HOCl}$ in given altitude rangos), chemintry and dyomics play an equally imporiant role.

With the measurement, over a significant period of time and over a wide spatial range, of a number of trace apecies concentrations, it bas become possible to produce climatological distributions of these compounde and even. for some of them, to infer reliable empirical models. As most of these modeis resul: from averaging a lage numbe: of observations, they may be compared to theoretical models which interd to simulate global average conditions by wiving the conservation equations based on chemical, radiative and dynamical considerations. Such comparison aliows the validation of both observational data and theoretical calculations. Moreover, ach atudy leads to a better understanding of the basic processes which control the observed distributions and to the identification of inconsistencies between theory and observations.

Ideally, in order to investigate all processes involved, comparison between theory and observations re quire on the one band multidimensional models and on the ather band atmopheric data sete covering the entire earti. However, because the data avalable sre limited and accurate multidimensional transport entire earti. Howeves, because the dave and diffult to achieve, "fist order" validation of the currently known chemical processes in the stratophere can be based on simpier one-dimensional calculations.

The purpase of this short paper in wo idericify major discrepancies between empirical models and theoretica models and to atress the need for additional observations in the atmospere and for further laboratory models and these differences ouggest either problems ssociated with observation techniques or errors in cbemical kipetica data (or the exintence of unknown processes which appear to play an important role). The model used for this investigation | 1 l extend from the earth's surface to the lowe? thermosphere. It includes the importan: cnemical and photochemical processes related to the oxygen, hydrogen, carbon, nitrogen and chlorine families. The chemical code is coupled with a radiative acheme which provides the beating rate due to absorption of colar radiation by ozone and the cooling rate due to the emission and absorption of lertestrial radiation by $\mathrm{CO}_{2}, \mathrm{~B}_{2} \mathrm{O}$ and $\mathrm{O}_{3} .[2]$ The vertical transport of the apecies is expreased by an eddy diffusion parameterization.

\section{COMPARISON BETWEEN THEORETICAL MODELS AND OBSERVATIONS}

As the model used hereafier is one-dimensional and produces global average vertical probles, the present

- National Cenier lor Atmospheric Research is funded by the National Science Foundation 


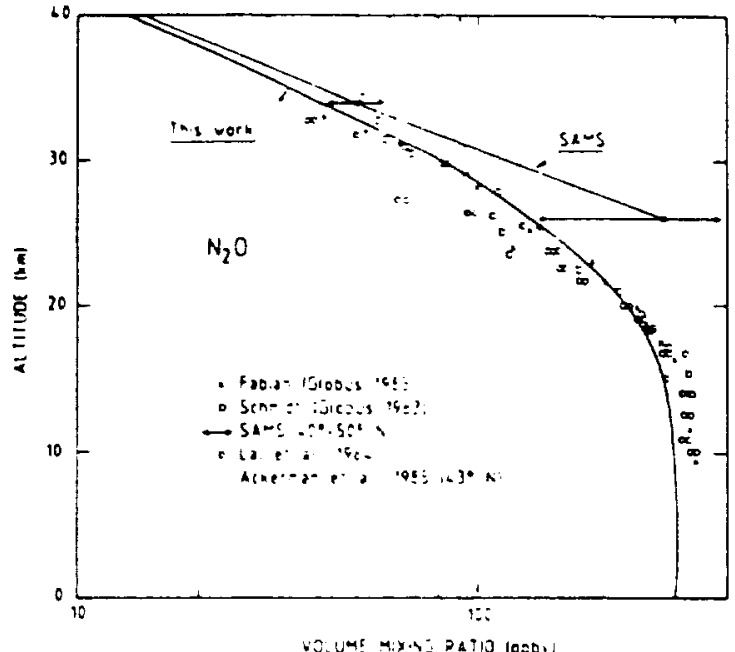

Fig. 1. Comparison be: zeen several observed distributions of nitrous oxide $3,4,5,6$ and a $1-D$ theoretical profile.

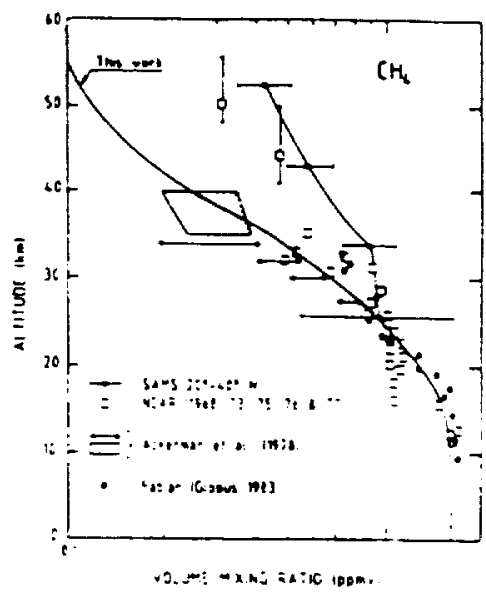

Fig. 2. Comparison between observed distributione of methase $[3,4,7\}$ are a I-D theoretical profile.

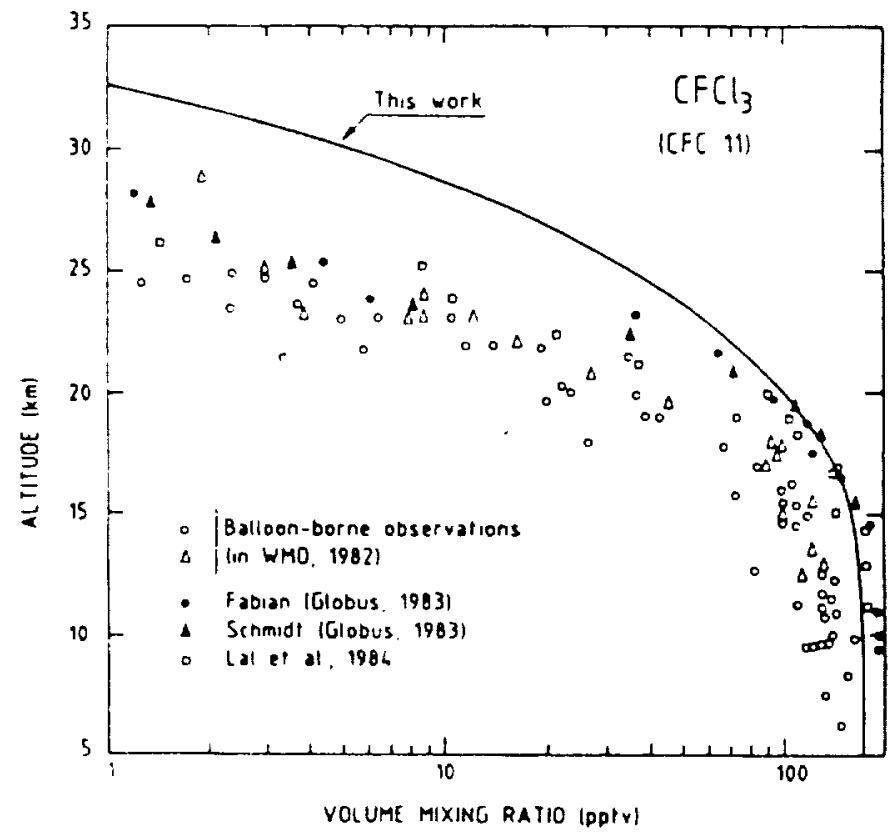

Fig. 3. Comparison between observed distributions of CFC-11 $\{3,3\}$ and a 1-D theoretica! profile. 
atudy will focus enentia!iy on the long-lived trace gases. However, some important and unexplained discrepanciea concerning the fast-rear:ing species will also be mentioned.

\section{Source Gues}

The calculated distributions of $\mathrm{x}_{2} \mathrm{O}, \mathrm{CH}_{4}, \mathrm{CCl}_{4}, \mathrm{CH}_{3} \mathrm{CCl}_{3}, \mathrm{CFC}-11$ and $\mathrm{CFC}-12$, are displayed in Firure 1-6. The acreement between ineoretical and observed vertical distributions is sood for $\mathrm{N}_{3} \mathrm{O}$

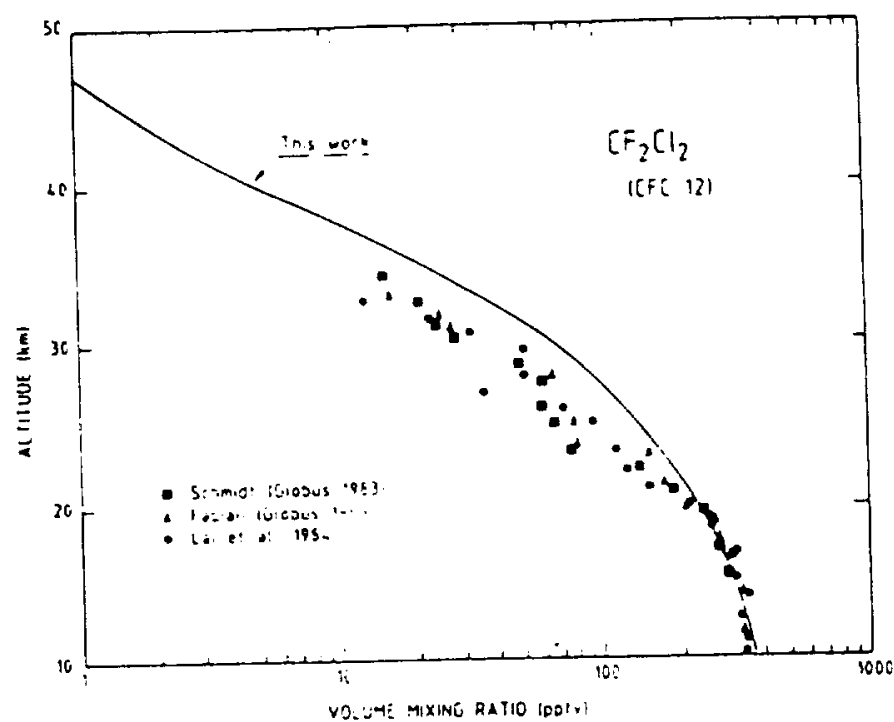

Fig. 1. Comprison between observed distributions of $C F C-12\{3,5 \mid$ and a $1-D$ theoretical profile.

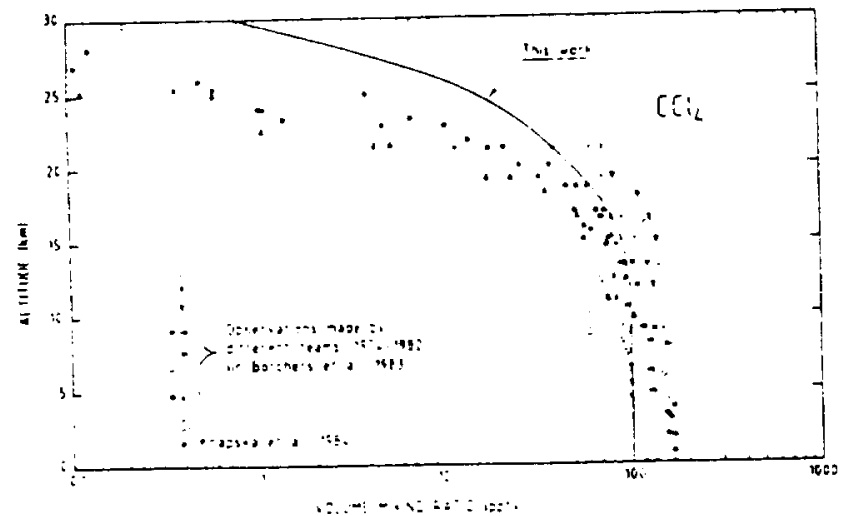

Fig. 5. Comprison between observed distributions of carbon tetrachloride $[B, 9] \geq$ ad a 1-D theoretical profile. 


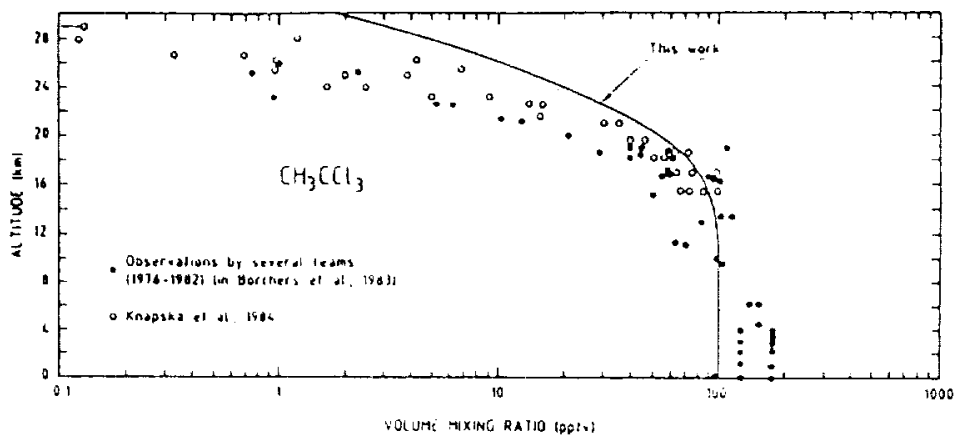

Fig. 6. Comparison between observed distributions of aeinyl chloroform $[8,9]$ and a $1-D$ theoretical profile.

and for $\mathrm{CH}_{4}$. In the latter case however large differences in the observations exist above $30 \mathrm{~km}$, making the comparison between model and obsenation diffcult. The :e!atively good agreement, in the case of $\mathrm{N}_{2} \mathrm{O}$, is not eurprising as the eddy diffusion coefincients whic: are used in the models (including the preaent model) are usually tured to ft the vertical profile of this particilar gas. For the precursor gases of active chlorise (e.g. the CFCs), the model tends to overestimate the mixing ratio, especialiy in the higher levels, except for CFC-12. Such discrepancy which appears in essentially all 1-D models hus bot yet been resolved. It can be due either to the use of an inadequate edjy difusion coefficient or to an underestimated lows rate (or to both). Indeed, it has been shown from theoretical considerations in that the specified value of the 1.D eddy diffusion coefficient shouid be a function of the lifetime of the irace-constituent. Moreover, uncertainties remain in the calculation of the penetration of sunlight in the Schumann-Runge bands, leading to uncertain photodissociation rates of the chlorobuorocarbons.

The calculated lifetime of the cource gases playing a majot role in the stratosphere is given in Table 1.

TABLE 1 Calculated Lifetime of the Source Gases

\begin{tabular}{lc}
\hline \multicolumn{1}{c}{ Species } & Lifetime (yrs) \\
\hline $\mathrm{N}_{2} \mathrm{O}$ & 165.6 \\
$\mathrm{CH}$ & 10.0 \\
$\mathrm{CH}_{3} \mathrm{Cl}$ & 1.5 \\
$\mathrm{CCl}_{4}$ & 68.8 \\
$\mathrm{CH}_{3} \mathrm{CCl}_{3}$ & 6.6 \\
$\mathrm{CFCl}_{3}(\mathrm{CFC}-11)$ & 86.6 \\
$\mathrm{CF}_{2} \mathrm{Cl}_{2}(\mathrm{CFC}-12)$ & 154.3 \\
$\mathrm{CFCl}_{2} \mathrm{CF}, \mathrm{Cl}(\mathrm{CFC}-113)$ & 129.8 \\
$\mathrm{CHF}_{2} \mathrm{Cl}_{(\mathrm{CFC}-22)}$ & 16.2 \\
-
\end{tabular}




\section{Active Guses and Temporary Reservoirs}

The concentration of uctive gases such as $\mathrm{OH}, \mathrm{HO}_{2}, \mathrm{O}, \mathrm{Cl}, \mathrm{ClO}$, etc is difficult to measure since their concentration is low and their chemical reacti, iy very high. A reliable comparison between theoretical

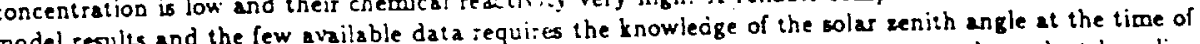
model resulis and the lew available data i concentration in the observed mass of the transport dependent long-live

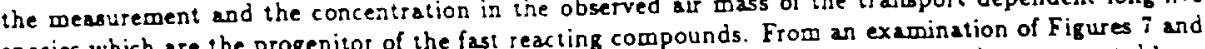
species which are the progenitor of the fast reacting compounds. From an exarica $[11,12,13,14\}$ have 8 , it can however be deduced that the most rexent measurerients of the OH radica li, 12,13 , $\mathrm{HO}_{2}$, the the same order of magnitude thas values provided by theoretical modeis but that, in the case redicted by values reported by Helten et al. 15 ; are in the lower stratosphere a faclor 100 larger thar: redicted by

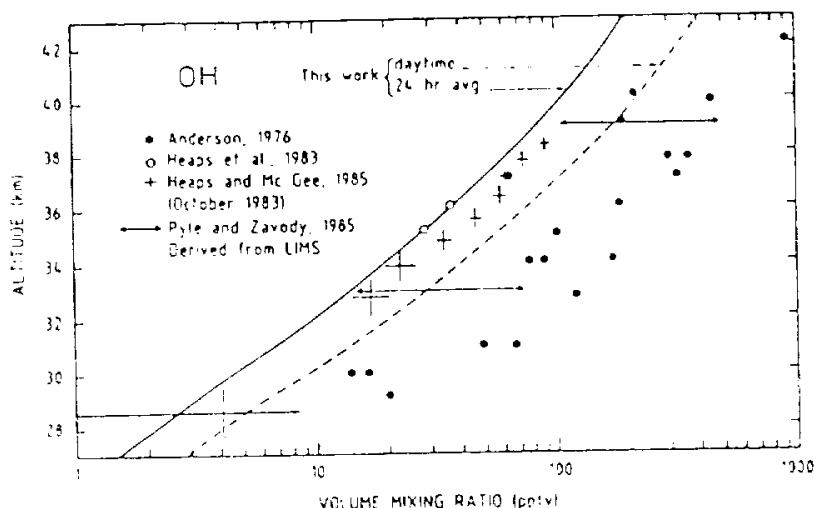

Fig. 7. Comparison between observed or indirectly deduced mixing ratis of $\mathrm{OB}\{11,12,13$, 14 and theoretical profiles (24 hout average and daytime average: mid-latitude; equinox).

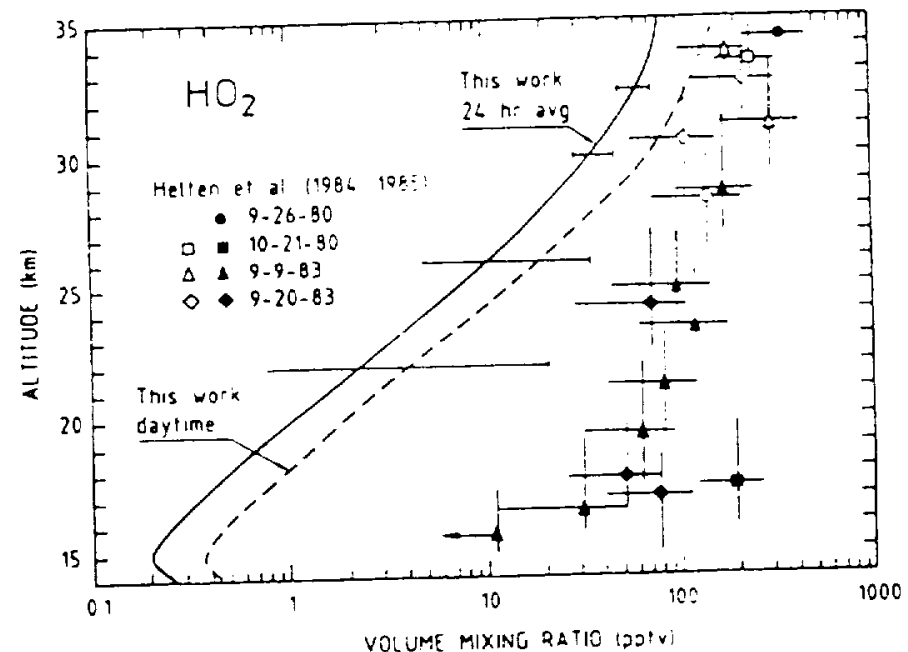

Fig. B. Comparison between observed mixing ratio of $\mathrm{HO}_{2}$ ' 15 ; and theoretical profles Fig. B. Comparison between observed mixing ratio or $\mathrm{HO}_{2}$, 
theory. If additional measurc aer:s ind to conörm these data. the p-esently accepted checrical scheme in in error for the hydrogen spec.es zi least, in the almosphesit lavei where the ozone concentration is the largest.

Efforts to mesure the vertical distr:'sution of temporary reservoirs have been reported only recently. Figurea 9 and 10 show that, especialiy for $\mathrm{ClONO}_{2}$, the data deduced irom infra-ted measurements, for example from the ATMOS experiment, ase consistent with a 24 hour-averaged model calculation.

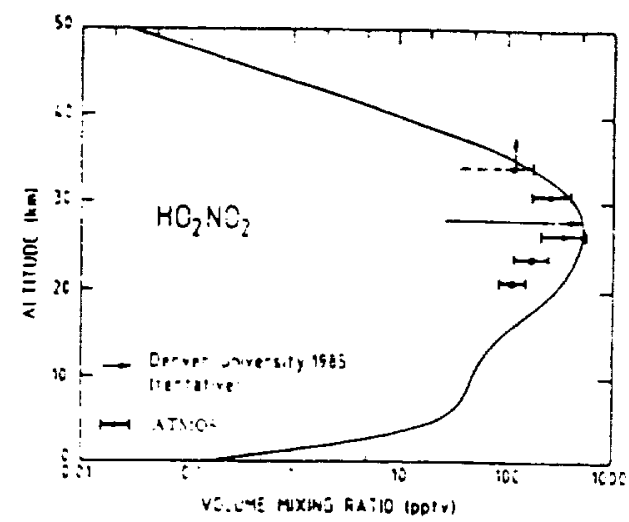

Fis. 9. Comparison between observations of $\mathrm{HO}_{2} \mathrm{NO}_{2} \mid 16$ i and a 24-hour average theoret ical proble (mid-12:itude, equinox).

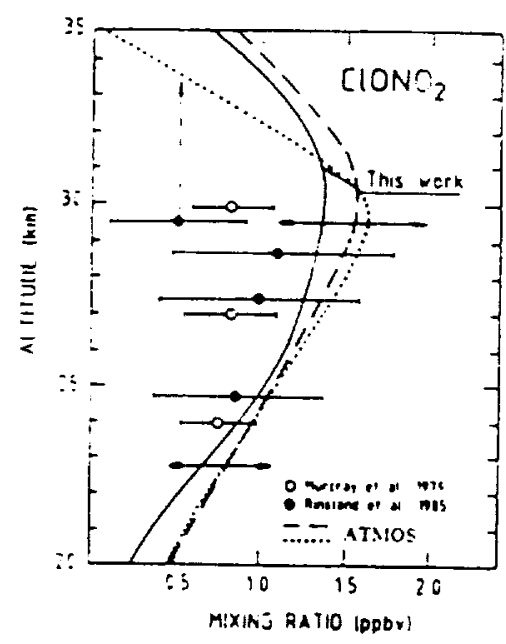

Fig. 10. Comparien between obmervation of $\mathrm{ClONO}_{2}[17,18,19]$ and a 24-hour average theoretical proble (mid-latitude, equinax). The dotted line and the dashed line refer to ATMOS data at $30^{\circ} N$ (sunset) at $47^{\circ} \mathrm{S}$ (sunriae) reapectively. 


\section{Nitric Acid and Ozone}

Finally, comparion between theory and observations is performed for 2 gases (HNO, and $\mathrm{O}_{3}$ ) which Finaly, comparion in the metasphert and a hose lifetime varies signiferntly with altitude and latisude. In are produced in the miatosphert and a hose lifetime varies signiterntly nith altude and laticude. In

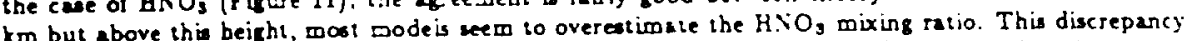
is emphasized by the fact that new treatment of the HNO, LMiS data 20 ) indicatea that the mixing ratio retrieved in the upper stralosphere thould be reduced by as much as a factor $2-5$

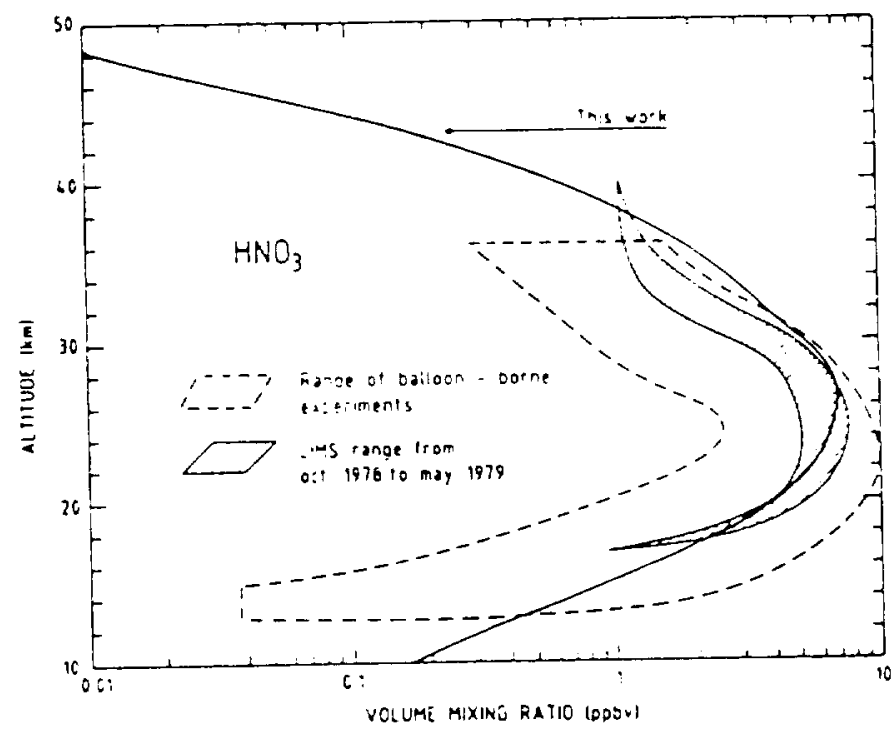

Fig. 11. Comparison beiween observations of aitric acid (balloon-borne experiments as $i$ IDis data) and a theoretica profle ( 24 hour average, mid-iatituoe, equibox).

Ozone has been measured ratinet oystematically and by different technigues over number of years. The vertical profile provided by the $[S$ Standard Atmosphere 21 which is in close agreement witi other daia bases is compared in Figure 12 with a model calculation. The :ieoretical concentrations are obviourty 20 :0 $40 \%$ lower than the observed values in the upper stratospheze. This orone imbalance obvioust 20 ing $(22,23)$ is not yet explained. It could be due either wo unknown

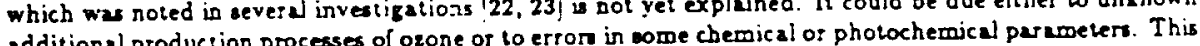
additional production processes of refects some unknown processes occurring in the atmospheric region

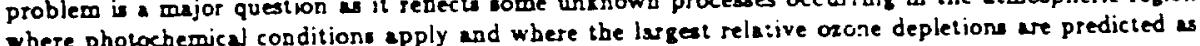
- response to the emiesion of CFCs.

\section{CONCLUSIONS}

Models reproduce most of the observed distribution of the trace epecies belonging to the oxygen, hydrogen. aitrogen and chlorine families. Some discrepanciea however remain, which retect errors or uncertintie in the chemical scheme currently adopted in the models. More work is thus needed to uncertsicas could explain the cause of these discrepancies. A more detail comparison between obserntions and theory, which should account for the latitudinal and sewonal variation of the trace species concentration, should involve multi-dimensional models. 


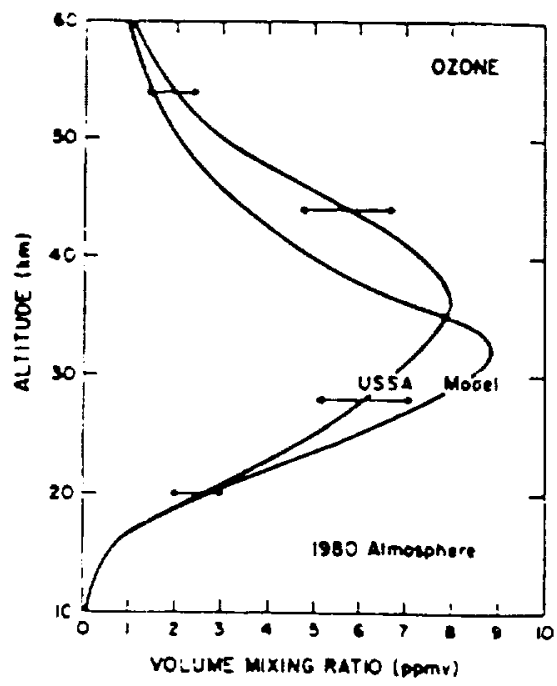

Fir. 12. Comperison besween the U.S. Standerd atmospnere model of ozone $|21|$ and a theoretical vertical distribution

\section{REFERENCES}

1. G. Brasseur, A. De Rudder and C. Tricot, J. Aimos. Chem., 3, 261 (1985).

2. J. J. Morcrette, Ph.D. Thesis, Lniversity of Lille, France (1984).

3. U. Schmidt, G. Kuleasa, E. Klein, E. P. Röth, P. Fabian and R. Borchers, Planet. Space Scrence, to be published (1986).

4. R. L. Jodes and J. A. Pyle, J. Geophys. Res., 80, 5263 (1984).

5. S. Lal, R. Borchen and P. Fabian, in Atmospheric Ozone (C. S. 7erefos and A. Ghazi, ede.), pp. 134-138 (1983).

6. M. Ackerman, C. Lippens. C. Muller, J. Vercheval, J. Beason, A. Girard, J. Laurent and M. P. Lemaitre, Geophys. Res. Lett., 10, 667 (1985).

7. M. Ackerman, D. Frimont, C. Muller and D. J. Wuebbles, Pure Appl. Geophya., 117, 367 (1978).

8. R. Borcher, P. Fabian and S. A. Penkelt, Naturuise, 70, 514 (1983).

9. D. Knapeka, U. Schmidt, C. Jebsen, G. Kulesse and J. Rudolph in Atmospheric Ozone (C. S. Zerefos and A. Ghazi, eds.) pp. 117-121, D. Reidel Publishing Co., Dordrecht, The Netherlands (1985).

10. J. R. Bolton, J. Geophys. Res., 01, 2681 (1986).

11. J. G. Anderson, Geophya. Res. Lett., S, 165 (1976).

12. W. S. Heaps and T. J. McGee, J. Geophys. Res., 88, 5281 (1983).

13. W. S. Keaps and T. J. MrGee, J. Geophyd. Res., 90,7913 (1985). 
11. J. A. Pyle and A. M. Zavoc:. Quart. J. Roy. Mcitcorol. Soc., 111 (1985).

15. M. Helten, W. Patz, D. A. Ethre!' and E. P. Röth, in Atmospheric Ozone (C. S. Zerefoo and A. Ghazi, eds.) pp. 196-200, D. Reicel Evib!istisg Co., Dordrech!, The Nethetiands (1985).

16. C. P. Rinsland, R. Zander. C. 3. Farmer, R. B. Norton, L. R. Brown, J. M. Ruesell III and J. H. Pask, Geophys. Res. Lett., 13, 761 (1956).

17. D. G. Mureray, A. Golaman, F. E. Mureray, F. J. Murcray and W. J. Williams, Geophys. Res. Lett., 0,857 (1979).

1B. C. P. Rinsland, A. Gold=2n, D G. Murcray, F. J. Mureray. F. S. Bonomo, R. D. Blatherwick, V. M Devi, M.A.H. Smith and P. I. Rinsiand, J. Geophys. Kes., D, 7931 (1985).

19. R. Zander, C. P. Rinsland, C. B. Fatmer, L. R. Brown and R. H. Norion, Geophys. Rea. Lett, 13, 75: (1986).

20. J. C. Gille and P. A. Bailey, private communication (1986).

21. U. S. Standard A:momphere, NOAA - S/T76-1562, U.S. Printir.B Ofice, Washington, D.C. (1976)

22. P. J. Crutren and L. Schoailz:. Pianc:. Space Sci, 31, 1009 (1983).

23. L. Froidevaux, Ph.D. Thesis, Caiffomia Institule of Techrology (1983). 